\title{
The impact of the reserve military neurosurgeon: practice, community, and service
}

\author{
Richard Menger, MD, MPA, ${ }^{1}$ Benjamin F. Mundell, PhD, ${ }^{2}$ J. Will Robbins, MD, ${ }^{3}$ Peter Letarte, MD, ${ }^{4}$ \\ and Randy Bell, MD, ${ }^{5}$ in conjunction with Council of State Neurosurgical Societies and \\ AANS/CNS Joint Committee of Military Neurosurgeons
}

\begin{abstract}
${ }^{1}$ Department of Neurosurgery, Louisiana State University Health Sciences Center, Shreveport, Louisiana; ${ }^{2 M a y o}$ Clinic School of Medicine, Rochester, Minnesota; ${ }^{3}$ Wright-Patterson Air Force Base, Dayton; ${ }^{4}$ Center for Neuro and Spine, Department of Surgery, Mercy Medical Center, Canton, Ohio; and 5 Uniformed Services University of Health Sciences, Bethesda, Maryland
\end{abstract}

OBJECTIVE Papers from 2002 to 2017 have highlighted consistent unique socioeconomic challenges and opportunities facing military neurosurgeons. Here, the authors focus on the reserve military neurosurgeon who carries the dual mission of both civilian and military responsibilities.

METHODS Survey solicitation of current active duty and reserve military neurosurgeons was performed in conjunction with the AANS/CNS Joint Committee of Military Neurosurgeons and the Council of State Neurosurgical Societies. Demographic, qualitative, and quantitative data points were compared between reserve and active duty military neurosurgeons. Civilian neurosurgical provider data were taken from the 2016 NERVES (Neurosurgery Executives Resource Value and Education Society) Socio-Economic Survey. Economic modeling was done to forecast the impact of deployment or mobilization on the reserve neurosurgeon, neurosurgery practice, and the community.

RESULTS Seventy-five percent (12/16) of current reserve neurosurgeons reported that they are satisfied with their military service. Reserve neurosurgeons make significant contributions to the military's neurosurgical capabilities, with $75 \%(12 / 16)$ having been deployed during their career. No statistically significant demographic differences were found between those serving on active duty and those in the reserve service. However, those who served in the reserves were more likely to desire opportunities for improvement in the military workflow requirements compared with their active duty counterparts $(p=0.04) ; 92.9 \%$ (13/14) of current reserve neurosurgeons desired more flexible military drill programs specific to the needs of practicing physicians. The risk of reserve deployment is also borne by the practices, hospitals, and communities in which the neurosurgeon serves in civilian practice. This can result in fewer new patient encounters, decreased collections, decreased work relative value unit generation, increased operating costs per neurosurgeon, and intangible limitations on practice development. However, through modeling, the authors have illustrated that reserve physicians joining a larger group practice can significantly mitigate this risk. What remains astonishing is that $91.7 \%$ of those reserve neurosurgeons who were deployed noted the experience to be rewarding despite seeing a $20 \%$ reduction in income, on average, during the fiscal year of a 6 -month deployment.

CONCLUSIONS Reserve neurosurgeons are satisfied with their military service while making substantial contributions to the military's neurosurgical capabilities, with the overwhelming majority of current military reservists having been deployed or mobilized during their reserve commitments. Through the authors' modeling, the impact of deployment on the military neurosurgeon, neurosurgeon's practice, and the local community can be significantly mitigated by a larger practice environment.

https://thejns.org/doi/abs/10.3171/2018.9.FOCUS18378

KEYWORDS Council of State Neurosurgical Societies; military neurosurgery; socioeconomics

$\mathrm{N}$ EUROSURGEONS may serve their country through a variety of service pathways. Military reserve service allows the neurosurgeon the opportunity to serve in the military part time while maintaining a fulltime civilian neurosurgical practice. General service re- quirements entail 1 weekend per month of drill time, generally at an operational support center, as well as 2 weeks of annual training with the military. Reservists are paid monthly drill pay as well as pay associated with their 2 weeks of annual training. However, they are subject to mo-

ABBREVIATIONS CSNS = Council of State Neurosurgical Societies; GWOT = Global War on Terrorism; HPSP = Health Professions Scholarship Program; NERVES = Neurosurgery Executives Resource Value and Education Society; ROTC = Reserve Officers' Training Corps; USUHS = Uniformed Services University of Health Sciences. SUBMITTED July 29, 2018. ACCEPTED September 12, 2018. INCLUDE WHEN CITING DOI: 10.3171/2018.9.FOCUS18378. 
bilization and deployments (generally 3 months to 1 year) per the needs of the armed services. Different accession bonuses and structures exist.

Mobilization refers to the activation from a part-time reservist to a temporary full-time active duty neurosurgeon. This can be within CONUS (the 48 contiguous states and the District of Columbia) or outside. Reservists can be deployed to areas of need, but more commonly they can serve at a CONUS military hospital, backfilling for active duty members who have been deployed. Mobilization slots are generally solicited as voluntary first but can become involuntary at the needs of the service. Reserve neurosurgeons will then leave their civilian positions and enter full-time military duty for the mandated period of time. Reservists are given as much lead time as possible and generally have 30 days' advanced notice for mobilization, but this is not always the case during times of war or national emergency. ${ }^{5}$

The purpose of this exercise is to shed light on the contributions of reserve neurosurgeons, compare demographic information with their active duty counterparts, and analyze opportunities for continued improvement in military service as a reserve neurosurgeon. Furthermore, economic modeling was performed to forecast the true impact that reserve service and its potential mobilizations has on neurosurgeons, hospitals, and communities.

\section{Methods}

The AANS/CNS Joint Committee of Military Neurosurgeons and Council of State Neurosurgical Societies (CSNS) solicited internet survey responses from neurosurgeons currently on active duty or currently in the reserves as a neurosurgeon.

Descriptive demographic information included service type, branch of service, military rank, commissioning source, military commitment, and deployment. Current service type refers to current affiliation with either active duty or reserve forces. Branch of service consists of the Army, Navy, or Air Force. Military rank stratifies service on the basis of officer rank: O-3, O-4, O-5, or O-6. Commissioning source represents the different platforms used to become an officer in the military. Commissions through bachelor degree platforms are noted via the respective service academies or Reserve Officers' Training Corps (ROTC). Attendance at the military medical school (Uniformed Services University of Health Sciences [USUHS]) or participation in the Health Professions Scholarship Program (HPSP) to attend civilian medical school under scholarship was recorded. Furthermore, direct commissioning options for a resident or a fully trained physician were also considered. In certain circumstances, officers can have multiple commissioning platforms. Military commitment was divided by the time frame of 2-3.9 years, 4-6.9 years, 7-10 years, and greater than 10 years. This was done to intentionally capture the different commitment algorithms.

Subjective data were considered regarding satisfaction with military service, including overall satisfaction (very pleased, somewhat pleased, or opportunities for improvement/did not meet my expectations). Military members were questioned as to whether they would recommend military service to their civilian colleagues, whether they intended to stay past their initial service commitment, and whether they specifically enjoyed treating military patients. Direct responses regarding feelings of patriotism, camaraderie, ability to focus on clinical neurosurgery, administrative responsibilities, deployment experience, and leadership opportunities were obtained. Active duty members were petitioned regarding their possible desire to transition to reserve service in the future.

Opportunities for improvement were solicited from active duty and reserve members. Active duty neurosurgeons were questioned regarding the possibilities of an increase in neurosurgery special pay; an increase in caseload/variety through a variety of civilian, veteran, and moonlighting platforms; a reduction in administrative responsibilities; or having more opportunities for research. Reserve questions included reform that could lead to more flexible drill schedules or more programs sensitive to physician work schedules, increased deployment opportunities, or the ability to treat more military neurosurgical patients.

\section{Statistical Methodology}

Binary analysis was created from descriptive data to aid in statistical powering as well as to create practically useful information. A 2-by-2 contingency table was established using Fisher's exact test. All $p$ values $\leq 0.05$ were considered significant for hypothesis testing of predictors. All statistical analysis was performed using Prism (version 7, GraphPad).

Binary analysis of branch-related information was separated into Army and Navy compared with Air Force. This was intentionally done given the history of the military residency training, the combined Army/Navy nature of the Walter Reed National Military Medical Center, and the relatively smaller size of the US Air Force. Analysis of rank of service was divided into those who are junior officers and those who are senior officers. O-3 and O-4 ranks were grouped together as either residents or relatively new attendings at a level of assistant professor. O-5 and O-6 ranks generally represent those who have been commissioned as an officer for 12 or more years and generally would be transitioning to the associate professor or full professor level. Similarly, military commitment was analyzed as those with 2-6.9 years of commitment and those with greater than 7 years. The split was intentionally done to capture those who have a longer commitment than an isolated medical school scholarship. Typical military scholarship for a civilian school (HPSP) payback is 4 years. The military medical school (USUHS) requirement is 7 years. Service academies generally require 5 years of service and ROTC 4 years independent of any medical school commitment incurred. Direct commission can be as little as 2 years. Commissioning source was analyzed to compare those with prolonged military training (ROTC, USUHS, and service academy) with those who have isolated medical commissions (HPSP and direct commission). This split was intentionally done to capture those who have a longer commitment through a variety of pathways. ${ }^{9}$ A comparison between the most important opportunities for improvement by active duty and reserve neurosurgeons was also analyzed. 
The 2016 Neurosurgery Executives Resource Value and Education Society (NERVES) Socio-Economic Survey was used to provide civilian data for income, compensation, collections, practice demographic, practice location, surgery volume, work relative value unit, new patient encounter volume, number of neurosurgeons per practice group, support staff per neurosurgeon, and cost of running a neurosurgeon's practice.

These data were used to model the impact of a deployment of a single reserve neurosurgeon on his or her annual salary during the year of a deployment along with quantifying the potential reduction in revenue for the practice and reduced capacity to serve the practice's patient population. Additional data from the Department of Defense Financial Management Regulation were used to illustrate the monetary compensation for a full-time military neurosurgeon. ${ }^{2}$ We further modeled the value risk taken by neurosurgeons, their practice, and their community by the deployment of a reserve neurosurgeon in a given 1-year period. We assumed that a reserve neurosurgeon would be deployed for 6 months in a given 1-year period when deployment occurs. We also accounted for a $14 \%$ likelihood that the deployed physician would continue to receive civilian pay as per previous study documentation. These data were used by and extrapolated from the article by Petinaux, who studied income trends from deployed Army Reserve physicians during the Global War on Terrorism (GWOT) ${ }^{8}$ Assumptions were also made in that no new neurosurgeons would be hired by the group during the time period.

No institutional review board was deemed necessary due to the open nonclinical survey.

\section{Results}

Twenty-seven active duty and 16 reserve neurosurgeons responded to the survey. Table 1 illustrates a comparison between the descriptive objective data of current active duty and reserve neurosurgeons. Data are relatively uniform. Not surprisingly, the reserve service had more neurosurgeons in the senior rank of colonel or captain (O-6): 7 of $16(43.75 \%)$ versus only 4 of $27(14.81 \%)$ of those on active duty. However, this difference was not statistically significant $(p=0.10)$. The majority of both active duty and reserve members of the military have been deployed: 20 of $27(74.07 \%)$ and 12 of $15(75.00 \%)$, respectively. Active duty neurosurgeons were more likely to have attended a service academy or an ROTC program. Reservists were more likely to have a direct commission.

Table 2 shows a comparison between the subjective data of active duty and reserve neurosurgeons. Overall, service as an active duty or reserve military neurosurgeon is an extremely positive experience. One hundred percent of active duty neurosurgeons (27/27) and 93.75\% (15/16) of reserve neurosurgeons specifically enjoyed treating military patients. Despite its hardships, deployment was noted as a rewarding experience for $85.00 \%$ (17/20) of active duty neurosurgeons and $91.67 \%$ (11/12) of reserve neurosurgeons. Feelings of camaraderie, patriotism, and the desire to obtain unique leadership opportunities were relatively similar between active duty and reserve neurosurgeons.
TABLE 1. Descriptive objective data of current active duty and reserve military neurosurgeons

\begin{tabular}{|c|c|c|c|}
\hline & \multicolumn{2}{|c|}{$\begin{array}{c}\text { No./Total No. of } \\
\text { Neurosurgeons (\%) }\end{array}$} & \multirow{2}{*}{$\begin{array}{c}p \\
\text { Value }\end{array}$} \\
\hline & Active Duty & Reserve & \\
\hline Branch* & & & 0.49 \\
\hline Army & $8 / 27(29.63)$ & $5 / 16(18.75)$ & \\
\hline Navy & $11 / 27(40.74)$ & $8 / 16(50.00)$ & \\
\hline Air Force & $8 / 27(29.63)$ & 3/16 (18.75) & \\
\hline Highest rank obtained† & & & 0.10 \\
\hline $0-3$ & 4/27 (14.81) & $1 / 16(6.25)$ & \\
\hline $0-4$ & 9/27 (33.33) & $2 / 16(12.50)$ & \\
\hline $0-5$ & 10/27 (37.04) & $6 / 16(37.50)$ & \\
\hline $0-6$ & $4 / 27(14.81)$ & $7 / 16(43.75)$ & \\
\hline Military commission $\ddagger$ & & & 0.51 \\
\hline Service academy/ROTC & 10/27 (37.04) & $3 / 15(20.00)$ & \\
\hline USUHS & $3 / 27(11.11)$ & $1 / 15(6.67)$ & \\
\hline HPSP & $17 / 27(62.96)$ & $3 / 15(20.00)$ & \\
\hline $\begin{array}{l}\text { Other program/direct } \\
\text { commission }\end{array}$ & $2 / 27(7.41)$ & $8 / 15(53.33)$ & \\
\hline Military commitment, yrs§ & & & 0.53 \\
\hline $2-3.9$ & $3 / 27(11.11)$ & $3 / 16(18.75)$ & \\
\hline $4-6.9$ & $6 / 27(22.22)$ & $4 / 16(25.00)$ & \\
\hline $7-10$ & $10 / 27(37.04)$ & $6 / 16(37.50)$ & \\
\hline$>10$ & $8 / 27(29.63)$ & $3 / 16(18.75)$ & \\
\hline Deployment & & & $>0.99$ \\
\hline Yes & $20 / 27(74.07)$ & $12 / 15(75.00)$ & \\
\hline No & $7 / 27$ (25.93) & $3 / 15(25.00)$ & \\
\hline
\end{tabular}

* Binary analysis of Army/Navy compared with Air Force.

† Binary analysis officer level 3 and 4 (0-3/0-4) compared with 0-5/0-6. $\ddagger$ Binary analysis of service academy, ROTC, and USUHS compared with HPSP/direct commission. The percentage is greater than $100 \%$ as multiple commissioning pipelines exist.

$\S$ Binary analysis of 2-6.9 years of service compared with greater than 7 years of service.

Opportunities for improvement for active duty neurosurgeons and reserve neurosurgeons are noted in Tables 3 and 4, respectively; $88.89 \%$ (24/27) of active duty neurosurgeons desire an increase in compensation, with $74.07 \%$ (20/27) desiring an increased caseload. Meanwhile, $92.86 \%$ (13/14) of reserve neurosurgeons desired a more flexible military drill schedule with more programs sensitive to the needs of practicing physicians. As such, those military neurosurgeons with reserve affiliation were more likely to value changes related to military work structure than their active duty counterparts $(p=0.04$; OR 4.54, 95\% CI 1.01-20.50). Specifically, this referred to more flexible military reserve drilling schedules and more programs sensitive to the needs of working physicians; $76.92 \%(10 / 13)$ of reserve neurosurgeons noted that more flexible military programs would be the most important innovation to improvement in military working conditions. Those on active duty saw a greater opportunity for improvement in their military experience by increased neurosurgery specialty pay and greater reduction of the 
TABLE 2. Subjective data of current active duty and reserve military neurosurgeons

\begin{tabular}{|c|c|c|c|}
\hline & \multicolumn{2}{|c|}{$\begin{array}{c}\text { No./Total No. of } \\
\text { Neurosurgeons (\%) }\end{array}$} & \multirow{2}{*}{$\begin{array}{c}\mathrm{p} \\
\text { Value }\end{array}$} \\
\hline & Active Duty & Reserve & \\
\hline $\begin{array}{l}\text { Overall how pleased w/ military } \\
\text { experience* }\end{array}$ & & & 0.73 \\
\hline Very pleased & $10 / 27(37.04)$ & $8 / 16(50.00)$ & \\
\hline Somewhat pleased & $8 / 27(29.63)$ & $4 / 16(25.00)$ & \\
\hline $\begin{array}{l}\text { Significant opportunities } \\
\text { for improvement/did not } \\
\text { meet my expectations }\end{array}$ & 9/27 (33.33) & $4 / 16(25.00)$ & \\
\hline $\begin{array}{l}\text { Would you recommend the } \\
\text { military to another neurosur- } \\
\text { geon? }\end{array}$ & & & 0.53 \\
\hline Yes & $15 / 26(57.69)$ & $11 / 16(68.75)$ & \\
\hline No & $11 / 26(42.31)$ & $5 / 16(31.25)$ & \\
\hline Feeling of pride \& patriotism & & & $>0.99$ \\
\hline Yes & $22 / 27(81.48)$ & $13 / 15(86.67)$ & \\
\hline No & $5 / 27(18.52)$ & 2/15 (13.33) & \\
\hline Feeling of camaraderie & & & $>0.99$ \\
\hline Yes & $16 / 27(59.26)$ & $10 / 15(66.67)$ & \\
\hline No & $11 / 27(40.74)$ & $5 / 15(33.33)$ & \\
\hline $\begin{array}{l}\text { Ability to focus on clinical medi- } \\
\text { cine/not business of practice }\end{array}$ & & & NA \\
\hline Yes & $12 / 27(44.44)$ & NA & \\
\hline No & $15 / 27(55.56)$ & NA & \\
\hline $\begin{array}{l}\text { Presence of unique leadership } \\
\text { opportunities }\end{array}$ & & & 0.48 \\
\hline Yes & $6 / 27(22.22)$ & $5 / 15(33.33)$ & \\
\hline No & $21 / 27(77.78)$ & 10/15 (66.67) & \\
\hline $\begin{array}{l}\text { Do you intend on staying past } \\
\text { your initial commitment? }\end{array}$ & & & $>0.99$ \\
\hline Yes & $8 / 27(29.63)$ & $4 / 16(25.00)$ & \\
\hline No & $14 / 27(51.85)$ & $11 / 16(68.75)$ & \\
\hline Undecided & $5 / 27(18.52)$ & $1 / 16(6.25)$ & \\
\hline $\begin{array}{l}\text { Do you specifically enjoy treat- } \\
\text { ing military patients? }\end{array}$ & & & 0.37 \\
\hline Yes & $27 / 27(100)$ & 15/16 (93.75) & \\
\hline No & $0 / 27(0)$ & $1 / 16(6.25)$ & \\
\hline Deployment rewarding† & & & $>0.99$ \\
\hline Yes & $17 / 20(85.0)$ & $11 / 12$ (91.67) & \\
\hline No & $3 / 20(15.0)$ & $1 / 12(8.33)$ & \\
\hline $\begin{array}{l}\text { Would you consider joining the } \\
\text { reserves? }\end{array}$ & & & NA \\
\hline Yes & $16 / 27(59.26)$ & NA & \\
\hline No & $11 / 27(40.74)$ & NA & \\
\hline Previous active duty & & & NA \\
\hline Yes & NA & $11 / 16(68.75)$ & \\
\hline No & NA & $5 / 16(31.25)$ & \\
\hline
\end{tabular}

* Binary analysis of those very pleased/somewhat pleased compared with those who saw opportunities for significant improvement/did not meet expectations.

$\dagger$ Of those who were deployed. military-civilian pay gap ( $\mathrm{p}=0.03$; OR $8.80,95 \%$ CI $1.00-78.10) ; 42.31 \%$ (11/26) of active duty neurosurgeons noted military pay to be the most important innovation to improve military working conditions.

Table 5 shows a comparison between those on active duty who would and those who would not consider transitioning to the reserve service after completion of their current active duty military obligation. Those who obtained a commission through a service academy, ROTC, or the military's medical school were less likely to desire further military service in the reserves $(p=0.06)$.

Civilian data from the NERVES survey are found in Table 6 and show the composite national data on compensation and productivity for civilian neurosurgeons. Payment structure for a full-time military neurosurgeon is found in Table 7.

A reserve neurosurgeon can expect that during the year of a 6-month deployment, he or she will see an approximate $20 \%$ reduction in his or her salary as well as a drop in new patient encounters, collections, work relative value units, and surgeries performed, and the practice/hospital will see an increase in operating cost per surgeon. This assumes no drop-off in civilian income or case volume leading up to or returning home from deployment.

By hiring a reserve neurosurgeon eligible for deployment, a practice exposes itself to an annual risk of that neurosurgeon being deployed for military service. This deployment would result in one less surgeon in the practice and community for a 6 -month period. Table 8 illustrates the impact reserve deployment has on the neurosurgery practice and community.

\section{Discussion}

This is the first study to directly survey and evaluate socioeconomic data from the current body of military neurosurgeons. It is also the first study to quantifiably demonstrate the impact and contributions of reserve military neurosurgeons. More than $75 \%$ of reserve neurosurgeons in our series have been deployed or mobilized during their career. Three-quarters of reserve neurosurgeons were pleased with their military service, reporting similar feelings of camaraderie, patriotism, and the desire to obtain unique leadership opportunities as their active duty counterparts. Furthermore, we have modeled the potential annual impact of deployment on reserve neurosurgeons, neurosurgery practice, and the local community. We have found, not surprisingly, that larger practices largely mitigate the impact that deployment can have on the neurosurgery practice and the local community.

\section{Impact on Surgeons}

Previous study in 2002 highlighted the unique challenges facing active duty military neurosurgeons. This was specifically related to case volume and income disparity. ${ }^{6}$ Menger et al. quantified those findings by noting that while the overwhelming majority of military neurosurgeons took great pride in their military service, they saw opportunities for improvement related to case volume, income differential, and a reduction in administrative responsibilities. However, these findings were dedicated almost exclusively to the active duty population. ${ }^{3}$ 
TABLE 3. Opportunities for improvement among current active duty neurosurgeons

\begin{tabular}{|c|c|c|}
\hline Question & Response & No./Total No. of Active Duty Neurosurgeons (\%) \\
\hline \multirow{5}{*}{$\begin{array}{l}\text { Which innovations could help improve current } \\
\text { military neurosurgery working conditions? }\end{array}$} & Increase in neurosurgery special pay & $24 / 27(88.89)$ \\
\hline & Increase in caseload/variety & $20 / 27(74.07)$ \\
\hline & Reduction in admin responsibilities & $15 / 27(55.56)$ \\
\hline & More opportunities for research & $15 / 27(55.56)$ \\
\hline & No improvements needed & $0 / 27(0)$ \\
\hline \multirow{5}{*}{$\begin{array}{l}\text { What is the most important innovation to improve } \\
\text { military neurosurgery working conditions? }\end{array}$} & Increase in neurosurgery special pay & $11 / 26(42.31)$ \\
\hline & Increase in caseload/variety & $11 / 26(42.31)$ \\
\hline & Reduction in administrative responsibilities & $4 / 26(15.38)$ \\
\hline & More opportunities for research & $0 / 26(0.00)$ \\
\hline & No improvements needed & $0 / 26(0.00)$ \\
\hline
\end{tabular}

Reserve military neurosurgeons have a dueling responsibility as a military officer and as a civilian neurosurgeon in their academic or private institution. ${ }^{4}$ As such, this study illustrates that their needs differ from their active duty counterparts. Reserve neurosurgeons tended to seek more flexible drill schedules (92.9\%). This illustrates the challenge of balancing civilian and military responsibilities. Reserve neurosurgeons also strongly desire more flexibility in terms of their military service.

Previous study has proven reserve service to be a financially viable opportunity during the first 3 years of service after residency. ${ }^{8}$ This is not without challenges. Deployment or mobilization of a reserve neurosurgeon to active duty can be disruptive. Our data illustrate that even with military pay, a deployed neurosurgeon will see, on average, a $20 \%$ reduction in his or her payment for that fiscal year.

A previous study by Petinaux noted that $86 \%$ and $76 \%$ of mobilized or deployed reserve physicians during the GWOT did not receive civilian income or benefits, respectively. ${ }^{8}$ The author calculated that a total of $\$ 1,339,000$ of income was lost in the 16 of 29 deployments, which resulted in an economic loss for the physicians during the GWOT. Those in a solo practice had the worst losses with additional layoffs of ancillary staff. Overall, 8 of 17 physicians surveyed $(47 \%)$ were considering resigning their commission due to the financial burden of deployment, which, in certain circumstances, resulted in outright payment to medical practices for clinical services lost. It is worth noting, in this series as well, that the main incentive for remaining in the military was patriotism (76\%). It is also worth noting that no neurosurgeons were surveyed in the Petinaux study. ${ }^{8}$

There is also the intangible opportunity cost of reserve military service. This includes being unavailable for one's civilian practice during mandatory military drill weekends and the 2 weeks of annual training. Senior partners, the administration, and the institution must, in different ways, be called on to support their reserve colleague. Furthermore, deployment can stunt research development, disrupt practice referral patterns, and greatly impact the physician's ability to run a private or academic practice. It can certainly impact overhead. This is outside of any family or social responsibilities.

What remains astonishing is that $91.7 \%$ of those reserve neurosurgeons who were deployed noted the experience to be rewarding, despite it being modeled that, on average, they would lose $\$ 251,545.99$ of income during the year of a 6-month deployment. Moreover, $75 \%$ of reserve neurosurgeons are pleased with their overall military reserve experience despite these limitations. Both active duty (100\%) and reserve $(93.8 \%)$ neurosurgeons specifically enjoy treat-

TABLE 4. Opportunities for improvement among current reserve neurosurgeons

\begin{tabular}{|c|c|c|}
\hline Question & Response & $\begin{array}{l}\text { No./Total No. of Reserve } \\
\text { Neurosurgeons }\end{array}$ \\
\hline \multirow{5}{*}{$\begin{array}{l}\text { Which innovations could help } \\
\text { improve current military } \\
\text { reserve neurosurgery working } \\
\text { conditions? }\end{array}$} & More flexible drill schedule \& more programs sensitive to physician work schedules & $13 / 14(92.86)$ \\
\hline & Increase in reserve salary & $5 / 14(35.71)$ \\
\hline & More opportunities to provide neurosurgery to military members & $4 / 14(28.57)$ \\
\hline & More deployment opportunities & $3 / 14(21.43)$ \\
\hline & No improvements needed & $0 / 14(0.00)$ \\
\hline \multirow{5}{*}{$\begin{array}{l}\text { What is the most important } \\
\text { innovation to improve military } \\
\text { reserve neurosurgery working } \\
\text { conditions? }\end{array}$} & More flexible drill schedule \& more programs sensitive to physician work schedules & 10/13 (76.92) \\
\hline & Increase in reserve salary & $1 / 13(7.69)$ \\
\hline & More opportunities to provide neurosurgery to military members & $1 / 13(7.69)$ \\
\hline & More deployment opportunities & $0 / 13(0.00)$ \\
\hline & No significant improvements needed & $1 / 13(7.69)$ \\
\hline
\end{tabular}


TABLE 5. Comparison between those on active duty considering service in the reserves and those without interest

\begin{tabular}{|c|c|c|c|}
\hline & \multicolumn{2}{|c|}{$\begin{array}{l}\text { No./Total No. of Active } \\
\text { Duty Neurosurgeons }\end{array}$} & \multirow[b]{2}{*}{$\begin{array}{c}\mathrm{p} \\
\text { Value }\end{array}$} \\
\hline & $\begin{array}{l}\text { Considering } \\
\text { Serving in } \\
\text { Reserves }\end{array}$ & $\begin{array}{l}\text { No Interest } \\
\text { in Serving } \\
\text { in Reserves }\end{array}$ & \\
\hline Branch & & & 0.67 \\
\hline Army & $6 / 16(37.50)$ & 2/11 (18.18) & \\
\hline Navy & $6 / 16(37.50)$ & $5 / 11(45.45)$ & \\
\hline Air Force & $4 / 16(25.00)$ & $4 / 11(36.36)$ & \\
\hline Highest rank obtained & & & $>0.99$ \\
\hline $0-3$ & $3 / 16(18.75)$ & $1 / 11(9.09)$ & \\
\hline $0-4$ & $5 / 16(31.25)$ & $4 / 11(36.36)$ & \\
\hline $0-5$ & $6 / 16(37.50)$ & $4 / 11(36.36)$ & \\
\hline $0-6$ & $2 / 16(12.50)$ & 2/11 (18.18) & \\
\hline Military commission* & & & 0.06 \\
\hline Service academy/ROTC & $4 / 16(25.00)$ & $6 / 11(54.54)$ & \\
\hline USUHS & $1 / 16(6.25)$ & 2/11 (18.18) & \\
\hline HPSP & $12 / 16(75.00)$ & $5 / 11(45.45)$ & \\
\hline $\begin{array}{l}\text { Other program/direct com- } \\
\text { mission }\end{array}$ & $2 / 16(12.5)$ & $0 / 11(0)$ & \\
\hline Military commitment, yrs & & & 0.23 \\
\hline $2-3.9$ & $2 / 16(12.50)$ & $1 / 11(9.09)$ & \\
\hline $4-6.9$ & $5 / 16(31.25)$ & $1 / 11(9.09)$ & \\
\hline $7-10$ & $4 / 16(25.00)$ & $6 / 11(54.55)$ & \\
\hline$>10$ & $5 / 16(31.25)$ & $3 / 11(27.27)$ & \\
\hline Deployment & & & 0.66 \\
\hline Yes & $11 / 16(68.75)$ & 9/11 (81.81) & \\
\hline No & $5 / 16(31.25)$ & 2/11 (18.18) & \\
\hline Deployment rewarding† & & & 0.47 \\
\hline Yes & $11 / 11(100)$ & $6 / 9(66.67)$ & \\
\hline No & $0 / 11(0.00)$ & $3 / 9(33.33)$ & \\
\hline $\begin{array}{l}\text { Overall how pleased w/ military } \\
\text { experience }\end{array}$ & & & $>0.99$ \\
\hline Very pleased & $7 / 16(43.75)$ & $3 / 11(27.27)$ & \\
\hline Somewhat pleased & $4 / 16(25.00)$ & $4 / 11(36.36)$ & \\
\hline $\begin{array}{l}\text { Significant opportunities } \\
\text { for improvement/did not } \\
\text { meet my expectations }\end{array}$ & $5 / 16(31.25)$ & 4/11 (36.36) & \\
\hline $\begin{array}{l}\text { Would you recommend the mili- } \\
\text { tary to another neurosurgeon? }\end{array}$ & & & 0.22 \\
\hline Yes & $11 / 16(68.75)$ & $4 / 10(40.00)$ & \\
\hline No & $5 / 16(31.25)$ & $6 / 10(60.00)$ & \\
\hline Feeling of pride \& patriotism & & & $>0.99$ \\
\hline Yes & $13 / 16(81.25)$ & $9 / 11(81.82)$ & \\
\hline No & $3 / 16(18.75)$ & 2/11 (18.18) & \\
\hline Feeling of camaraderie & & & $>0.99$ \\
\hline Yes & $9 / 16(56.25)$ & $7 / 11(63.64)$ & \\
\hline No & $7 / 16(43.75)$ & $4 / 11(36.36)$ & \\
\hline
\end{tabular}

CONTINUED IN NEXT COLUMN »
» CONTINUED FROM PREVIOUS COLUMN

TABLE 5. Comparison between those on active duty considering service in the reserves and those without interest

\begin{tabular}{|c|c|c|c|}
\hline & $\begin{array}{l}\text { No./Total } \mathrm{Nc} \\
\text { Duty Neuro }\end{array}$ & $\begin{array}{l}\text { 0. of Active } \\
\text { osurgeons }\end{array}$ & \\
\hline & $\begin{array}{l}\text { Considering } \\
\text { Serving in } \\
\text { Reserves }\end{array}$ & $\begin{array}{l}\text { No Interest } \\
\text { in Serving } \\
\text { in Reserves }\end{array}$ & $\begin{array}{c}\mathrm{p} \\
\text { Value }\end{array}$ \\
\hline $\begin{array}{l}\text { What is the most important in- } \\
\text { novation to improve active duty } \\
\text { military neurosurgery working } \\
\text { conditions? } \neq\end{array}$ & & & 0.42 \\
\hline $\begin{array}{l}\text { Increase in neurosurgery } \\
\text { special pay }\end{array}$ & $5 / 15(33.33)$ & $6 / 11(54.55)$ & \\
\hline Increase in caseload/variety & $8 / 15(53.33)$ & $3 / 11(27.27)$ & \\
\hline $\begin{array}{l}\text { Reduction in admin respon- } \\
\text { sibilities }\end{array}$ & $2 / 15(13.33)$ & $2 / 11(18.18)$ & \\
\hline $\begin{array}{l}\text { More opportunities for } \\
\text { research }\end{array}$ & $0 / 15(0.00)$ & $0 / 11(0.00)$ & \\
\hline No improvements needed & $0 / 15(0.00)$ & $0 / 11(0.00)$ & \\
\hline $\begin{array}{l}\text { What is the most important } \\
\text { innovation to improve reserve } \\
\text { military neurosurgery working } \\
\text { conditions?§ }\end{array}$ & & & 0.62 \\
\hline $\begin{array}{l}\text { More flexible drill schedule } \\
\text { and more programs } \\
\text { sensitive to physician } \\
\text { work schedules }\end{array}$ & $4 / 12(33.33)$ & $3 / 6(50.00)$ & \\
\hline Increase in reserve salary & 4/12 (33.33) & 2/6 (33.33) & \\
\hline $\begin{array}{l}\text { More opportunities to } \\
\text { provide neurosurgery to } \\
\text { military members }\end{array}$ & $3 / 12(25.00)$ & $1 / 6(16.67)$ & \\
\hline $\begin{array}{l}\text { More deployment oppor- } \\
\text { tunities }\end{array}$ & $1 / 12(8.33)$ & $0 / 6(0.0)$ & \\
\hline $\begin{array}{l}\text { No significant improvements } \\
\text { needed }\end{array}$ & $0 / 12(0.00)$ & $0 / 6(0.0)$ & \\
\hline
\end{tabular}

${ }^{*}$ Percentage greater than $100 \%$ as multiple commissioning pipelines exist. Binary comparison of those in service academy/ROTC and USUHS versus those in HPSP or direct commission.

† Of those who had deployed.

‡ Set against pay.

$\S$ Anticipated improvements-respondents have yet to serve in a reserve capacity—compared with flexible drill schedule.

ing military patients. The main area for improvement involves the flexibility allotted for military reserve neurosurgeons to balance their civilian and military careers while in a reserve military status. Policy can be geared to bridge that need. For example, the Critical Wartime Specialties designation allows physicians in certain specialties to have more relaxed and flexible drill requirements in certain circumstances. However, this is at the discretion of the local commanding officer and subject to change. Policy exploring more innovative and flexible drilling algorithms for surgical subspecialists seems to be the single greatest need expressed by reserve force members. 
TABLE 6. Socioeconomic data from civilian neurosurgeons (NERVES Socio-Economic Survey ${ }^{7}$ )

\begin{tabular}{|c|c|c|}
\hline & $\begin{array}{l}\text { Response } \\
\text { for Average } \\
\text { Civilian } \\
\text { Neurosurgeon }\end{array}$ & $\begin{array}{l}\text { Value for } \\
\text { a Military } \\
\text { Reserve } \\
\text { Service on a } \\
\text { Neurosurgeon } \\
\text { Eligible for } \\
\text { Deployment* }\end{array}$ \\
\hline \multicolumn{3}{|l|}{ Geography } \\
\hline East & $11.4 \%$ & \\
\hline South & $46.8 \%$ & \\
\hline Midwest & $22.4 \%$ & \\
\hline West & $19.2 \%$ & \\
\hline Median annual compensation & $\$ 710,460$ & $\$ 581,988 \dagger$ \\
\hline Median annual collectionsł & $\$ 850,522$ & $\$ 425,261$ \\
\hline Median annual wRVU & 9167 & 4583 \\
\hline Median collection per wRVU & $\$ 84$ & \\
\hline $\begin{array}{l}\text { Practices using wRVU for compen- } \\
\text { sation purposes }\end{array}$ & $48 \%$ & \\
\hline Median annual no. of surgeries & 246 & $\begin{array}{r}123 \text { (commu- } \\
\text { nity surgeries) }\end{array}$ \\
\hline \multicolumn{3}{|l|}{ Median call pay } \\
\hline Trauma & $\$ 2450$ & \\
\hline Emergency department & $\$ 1000$ & \\
\hline Median no. of neurosurgeons/group & 6 & \\
\hline Median no. of staff per neurosurgeon & 4 & \\
\hline Median no. of new patients/yr & 343 & 171 \\
\hline $\begin{array}{l}\text { Median operating costs/FTE neuro- } \\
\text { surgeon }\end{array}$ & $\$ 483,050$ & $\$ 724,575$ \\
\hline \multicolumn{3}{|l|}{ Practice type } \\
\hline Private practice & $41.5 \%$ & \\
\hline Hospital & $18.3 \%$ & \\
\hline Academic & $40.0 \%$ & \\
\hline Other & $0.2 \%$ & \\
\hline
\end{tabular}

FTE = full-time equivalent; $w R V U=$ work relative unit.

* Assumes 6-month deployment.

$\dagger$ Includes a 6 -month deployment and a $14 \%$ chance of civilian payment during deployment for 6 months, with 6 months of military pay estimated to be $\$ 177,026.28$ for an 0-5 officer with dependents on the basis of annual pay, allowances, and bonuses.

$\ddagger$ Excludes call pay.

\section{Impact on Employers}

In 2004, during the GWOT, nearly one-third of all deployed members of the US military were reserve or guard members. ${ }^{1}$ The Congressional Budget Office investigated the burden placed on employers of reserve service members. Specifically, they noted that those with the highest burden were self-employed reservists, small businesses with limited key personnel, and those whose business focused on highly specific skills. It is clear that physicians, especially neurosurgeons, largely fall into these categories.

Our data do illustrate a risk taken on by hospital systems and practices in employing a reserve military neu-
TABLE 7. Annual payment of a full-time military neurosurgeon

\begin{tabular}{lc}
\hline \multicolumn{1}{c}{ Military Payment } & Amount \\
\hline Annual payment* & $\$ 88,272.00$ \\
\hline Basic allowance for housing & $\$ 20,710.80$ \\
\hline Basic allowance for subsistence & $\$ 3043.56$ \\
\hline Variable special pay & $\$ 9999.96$ \\
\hline Board certification pay & $\$ 3999.96$ \\
\hline Additional special pay & $\$ 15,000$ \\
\hline Incentive special pay (2016) & $\$ 36,000$ \\
\hline
\end{tabular}

* Modeled as an 0-5 with 12 years of service.

$\dagger$ Assumes dependents and in the Washington, DC, area.

rosurgeon. It is not surprising, like other data, that those in smaller practices feel the impact the most. As with any business, the scale of a neurosurgical practice, in terms of number of surgeons, allows for absorbing production losses associated with reduced resources, in our case the deployment of a surgeon. During a deployment, due to increased operating costs per neurosurgeon, a practice or hospital could essentially be faced with the decision to terminate ancillary personnel.

It becomes clear through this algorithm that smaller practices would shoulder a greater burden if a reserve neurosurgeon were to be deployed. If a solo practitioner in private practice were to be deployed, collections would be zero with no chance for ancillary income. A multispecialty group with 20 practitioners would be able to absorb that loss much more easily. It would also intuitively make sense that things like local reputation and referral patterns would be less likely to be disrupted. Furthermore, we hypothesize, without tangible data, that larger practices would be more likely to be able to supplement the income of a deployed neurosurgeon than a smaller practice.

\section{Impact on Communities}

Deployment impacts the community that a neurosurgeon serves. Assuming that all providers continue to do the same amount of work, the number of new patients in the community that can be seen would decrease during the year of a deployment. The number of surgeries performed in the community would also decrease, as the community would be missing one neurosurgeon. In 2016, the average civilian neurosurgeon performed a mean of 246 cases (Table 8). Depending on the deployed surgeon's practice size, this would be reduced to anywhere from 185 to 240 cases by the hiring of a reserve neurosurgeon during 1 year of deployment. In 2016, the average civilian neurosurgeon saw a median of 343 new patients annually. Depending on practice size, this would be reduced to anywhere between 257 and 334 patients during a year that a reserve neurosurgeon is deployed. This could create a situation where fewer people would be able to receive care, partners could be forced to increase their workload, or patients would look to receive neurosurgery from a competing healthcare entity.

Challenges that are more difficult to quantify could also greatly impact the local community. These include the trauma status of the local hospital dependent on neu- 
TABLE 8. Impact by practice group size assuming a 6-month deployment in a fiscal year

\begin{tabular}{|c|c|c|c|c|c|}
\hline & \multirow{2}{*}{$\begin{array}{l}\text { Average Civilian } \\
\text { Neurosurgeon }\end{array}$} & \multicolumn{4}{|c|}{ No. of Neurosurgeons in Practice } \\
\hline & & 2 & 6 & 12 & 20 \\
\hline Median annual collections per neurosurgeon & $\$ 850,522$ & $\$ 637,892$ & $\$ 779,645$ & $\$ 815,084$ & $\$ 829,259$ \\
\hline Median no. of annual surgeries per neurosurgeon & 246 & 185 & 226 & 236 & 240 \\
\hline Median no. of new patients/yr per neurosurgeon & 343 & 257 & 314 & 329 & 334 \\
\hline Median operating costs per FTE neurosurgeon & $\$ 483,050$ & $\$ 724,575$ & $\$ 531,355$ & $\$ 505,007$ & $\$ 495,762$ \\
\hline
\end{tabular}

Civilian data are from the 2016 NERVES Socio-Economic Survey. ${ }^{7}$ Military data are from the Department of Defense pay chart and survey-specific data.

rosurgical coverage, distance traveled for healthcare, and wait times for neurosurgery.

Logically, it appears that a solo neurosurgery provider covering call at a local hospital in a relatively rural area would see his or her practice and community disrupted the most. The neurosurgeon would be away from his or her family while simultaneously shouldering a reduction in income. A hospital may lose intermittent trauma status. Economic streams for the hospital could be disrupted, and the job security of ancillary staff could be in jeopardy. Patients might also have to travel greater distances to receive neurosurgery care. This scenario contrasts dramatically with a multispecialty academic practice in a major city or a highly developed private practice group with a preferred hospital referral network.

\section{Limitations}

The study is limited by its survey solicitation format of a cohort of military members. Responses are subject to the individual reporting biases that are commonly seen. Furthermore, given the smaller sampling sizes, limitations of statistical power become considerable. Finally, it is worth directly noting that responses are by their very nature individualized and cannot capture the entire military neurosurgical experience, which is not completely reproducible. Rather, these data illustrate insight into the individual experiences of the 16 military reserve neurosurgeons who responded. As with any modeling algorithm, interpretation should be done in light of assumptions made; more realistic estimates are best quantified by large-scale findings. The authors must also acknowledge that not all bonuses or payments are available for reserve members mobilized to active duty. For example, variable special pay is only given to those reservists mobilized for 1 year or greater. The purpose of this report was to illustrate the contributions of reserve members and the general impact this has on the community.

\section{Future Directions}

Findings of these data should be integrated into policy adjustments to improve retention and recruitment of neurosurgery in the reserve services. Significant future investigation is warranted to illustrate the actual tangible fiscal and clinical impact that reserve service has on the practicing neurosurgeon and community. This can be accomplished through the use of actual Department of Defense data regarding manpower of military neurosurgeons. These data can be solicited by petition through the Defense Manpower Data Center.

\section{Conclusions}

This is the first data series evaluating service in the military as a reserve (part-time) neurosurgeon. Reserve neurosurgeons make substantial contributions to the military's neurosurgical capabilities, with the overwhelming majority of current military reservists having been deployed (or mobilized). Reserve neurosurgeons have similar feelings of patriotism, camaraderie, and pride in taking care of military patients as their active duty (full-time) counterparts. Illustrating their dual mission as civilian and military clinicians, $92.8 \%$ of reserve neurosurgeons desired a more flexible military reserve drill schedule with more programs sensitive to the needs of practicing physicians. What remains astonishing is that $91.7 \%$ of those reserve neurosurgeons who were deployed noted the experience to be rewarding, despite seeing a $20 \%$ reduction in income on average during that fiscal year.

\section{Acknowledgments}

We acknowledge Austin Menger, BS, MS, for his statistical expertise. We also acknowledge Todd Barnes, MBA, for his obtainment of the NERVES study data.

\section{References}

1. Congressional Budget Office: The Effects of Reserve Call-Ups on Civilian Employers. Washington, DC: Congressional Budget Office, 2005 (https://www.cbo.gov/ sites/default/files/cbofiles/ftpdocs/63xx/doc6351/05-11reserves.pdf) [Accessed October 11, 2018]

2. Department of Defense: Financial Management Regulation: Volume 7A: Military Pay Policy-Active Duty and Reserve Pay. Arlington, VA: Department of Defense, 2017 (http://comptroller.defense.gov/Portals/45/documents/ fmr/Volume_07a.pdf) [Accessed October 11, 2018]

3. Menger R, Robbins JW, Bell R: Military neurosurgery socioeconomic data: benefits, challenges, and opportunities. Neurosurgery [epub ahead of print], 2017

4. Menger RP, Wolf ME, Lang RW III, Smith DR, Nanda A, Letarte P, et al: Military neurosurgery: a range of service options. Neurosurgery 78:765-774, 2016

5. Military Times: Guard \& Reserve Handbook: Activation and Deployment. Vienna, VA: Military Times (http://ec.militarytimes.com/guard-reserve-handbook/ activation-deployment/types-of-activation/) [Accessed October 11, 2018]

6. Moquin RR, Ecklund JM: Socioeconomic issues of United States military neurosurgery. Neurosurg Focus 12(4): e6, 2002

7. Neurosurgery Executives' Resource Value \& Education Society: Socio-Economics Survey. Charlotte, NC: Neurosurgery Executives' Resource Value \& Education 
Society (https://www.nervesadmin.com/socio-economicsurvey) [Accessed October 11, 2018]

8. Petinaux B: The financial impact of deployments on reserve health care providers. Mil Med 173:729-733, 2008

9. Uniformed Services University of the Health Sciences: What You Need to Know. Bethesda, MD: Uniformed Services University of the Health Sciences, 2018 (https:// www.usuhs.edu/sites/default/files/media/medschool/pdf/ whatyouneedtoknow.pdf) [Accessed October 11, 2018]

\section{Disclaimer}

The views expressed are those of the authors and do not reflect the official policy or position of the US Air Force, US Navy, Department of Defense, or the US Government.

\section{Disclosures}

The authors report no conflict of interest concerning the materials or methods used in this study or the findings specified in this paper.

\section{Author Contributions}

Conception and design: all authors. Acquisition of data: Menger, Robbins, Bell. Analysis and interpretation of data: Menger, Mundell, Robbins. Drafting the article: Menger, Robbins. Critically revising the article: all authors. Reviewed submitted version of manuscript: all authors. Approved the final version of the manuscript on behalf of all authors: Menger. Statistical analysis: Menger, Mundell. Administrative/technical/material support: Menger, Bell. Study supervision: Menger, Bell.

\section{Correspondence}

Richard Menger: LSU Health Sciences Center-Shreveport, Shreveport, LA. richard.menger@gmail.com. 